\title{
DEVELOPMENT OF THE INVENTORY OF TRADITIONAL AND MODERN APPROACHES TO PARENTING: RELIABILITY AND VALIDITY
}

\author{
Huri Gül BAYRAM GÜLAÇTI*
}

\begin{abstract}
The main aim of this study** was to develop a reliable and valid measurement tool for exploring parents' traditional and modern approaches to parenting. Although some scales focus on attitudes about parenthood, many of those are out of date or do not appropriately focus on parents' attitudes toward parenting in the Turkish culture. Thus, a new scale measuring parental attitudes in the Turkish cultural context is needed for proper assessment. With that goal, this study was undertaken with three separate samples including mothers and fathers. Principal component analyses were carried out to determine the factor structure of the scale and results showed that the scale has two dimensions: traditional and modern approaches. Confirmatory factor analyses were also conducted to check the two-factor structure and suggested that the scale has an acceptable model fit. Finally, the internal consistency scores and significant associations demonstrated that the scale has good psychometric properties in terms of reliability and validity. The current study has thus provided a reliable and valid scale for researchers to investigate and assess parents' traditional and modern attitudes toward parenting.
\end{abstract}

Keywords: Traditional Approach, Modern Approach, Parenting, Reliability, Validity.

\section{EBEVEYNLİĞE GELENEKSEL VE MODERN YAKLAŞIMLAR ÖLÇEĞİ'NİN GELISSTİIILMESI: GÜVENIRLIKK VE GEÇERLIK}

\section{ÖZ}

Mevcut çalışmanın temel amacı, ebeveynlerin ebeveynliğe geleneksel ve modern yaklaşımlarını araştıran güvenilir ve geçerli bir ölçüm aracı geliştirmektir. Bazı ölçekler ebeveynlikle ilgili tutumlara odaklansa da, bazıları güncelliğini yitirmiş veya Türk kültüründe ebeveynlerin ebeveynliğe dair tutumlarına uygun bir biçimde odaklanmamıştır. Bu nedenle, doğru bir değerlendirme için Türk kültürel bağlamında ebeveyn tutumlarını ölçen bir ölçeğe ihtiyaç olduğu düşünülmektedir. Çalışmada, anne ve babalardan oluşan üç ayrı örneklem bulunmaktadır. Ölçeğin faktör yapısını belirlemek için Temel Bileşen Analizleri yapılmış ve sonuçlar ölçeğin geleneksel ve modern yaklaşımlar olmak üzere iki boyutunun olduğunu göstermiştir. Ayrıca iki faktörlü yapıyı test etmek için Doğrulayıcı Faktör Analizleri yapılmış ve ölçeğin kabul edilebilir bir model uyumuna sahip olduğu önerilmiştir. Son olarak, iç tutarlılık puanları ve anlamlı ilişkiler, ölçeğin güvenirlik ve geçerlik açısından iyi psikometrik özelliklere sahip olduğunu göstermiştir. Özetle, mevcut çalışma, araştırmacılar için ebeveynlerin ebeveynliğe dair geleneksel ve modern tutumlarını araştırmak için güvenilir ve geçerli bir ölçek göstermektedir. Ölçek, ebeveynlerin ebeveynliğe yönelik geleneksel veya modern tutumlarını değerlendirmek için kullanılabilir.

Anahtar Kelimeler: Geleneksel Yaklaşım, Modern Yaklaşım, Ebeveynlik, Güvenirlik, Geçerlik.

Atıf: BAYRAM GÜLAÇTI, H. G. (2021). “Ebeveynliğge Geleneksel ve Modern Yaklaşımlar Ölçeği'nin Geliştirilmesi: Güvenirlik ve Geçerlik”, İMGELEM, 5 (9): 295-311.

Citation: BAYRAM GÜLAÇTI, H. G. (2021). "Development of the Inventory of Traditional and Modern Approaches to Parenting: Reliability and Validity", IMGELEM, 5 (9): 295-311.

Başvuru / Received: 24 Ağustos / August 2021.

Kabul / Accepted: 15 Ekim / October 2021.

Araştırma Makalesi / Research Article.

\footnotetext{
* PhD, Ankara Hacı Bayram Veli University, Faculty of Letters, Department of Psychology, E-mail: hurigulbayram@gmail.com, ORCID Number: 0000-0002-1766-7050

** Ethical approval was received from the institutional ethics board at Middle East Technical University in Ankara, Turkey (Approval Date: 03.05.2016, Approval Number: 2016-SOS-093)
} 


\section{Development of the Inventory of Traditional and Modern Approaches to Parenting: Reliability and Validity}

\section{INTRODUCTION}

Individuals' gender role ideologies could be categorized as encompassing traditional or non-traditional gender roles (Blackstone 2003). Traditional and non-traditional gender role attitudes pertain to different roles within the family and are associated with the power-related differences between partners. In the traditional approach, homemaker and childcare roles are attributed to women while provider and breadwinner roles are attributed to men (Corrigall \& Konrad 2007; Rogers \& Amato 2000). On the other hand, the non-traditional roles emphasize more balanced power relations between women and men, such as the equal sharing of financial, household, and childcare responsibilities (Corrigall \& Konrad 2007; Rogers \& Amato 2000).

Over the years, it has become evident that gender role ideologies may be altered by socioeconomic and cultural changes (Rogers \& Amato 2000; Scott 2006). However, the impacts of these attitudes on domestic roles (Copur et al. 2007), views about parenthood (Bernhardt \& Goldscheider 2006), and parenting practices (Nangle et al. 2003) remain to be elucidated. Even in dual-earner families, there is often a traditional division of labor between women and men (Bartley et al. 2005). For example, in Turkey, despite many women having negative attitudes toward traditional gender roles, they largely remain responsible for all domestic tasks (Copur et al. 2007) while men are less likely to share the housework with women (Copur et al. 2010).

Moreover, gender role attitudes are among the important factors associated with perceptions of parenthood (Bernhardt \& Goldscheider 2006). Men and women who embrace more traditional gender roles evaluate the benefits (i.e. positive outcomes) and costs (i.e. negative outcomes) of being a parent differently than those who advocate egalitarian or nontraditional gender roles. In particular, men with traditional gender role attitudes have more concerns about the negative outcomes of being a parent compared to men with non-traditional egalitarian attitudes (Bernhardt \& Goldscheider 2006). On the contrary, women with traditional gender role attitudes are more likely to perceive the benefits of having children compared to women with non-traditional egalitarian attitudes (Bernhardt \& Goldscheider 2006).

Researchers have also observed the impact of traditional views about parenting on childcare attitudes and practices. For example, it was found that fathers in families with nontraditional gender role attitudes tended to be involved in childcare more than those in traditional families (Nangle et al. 2003). Similarly, fathers with more egalitarian gender role attitudes were more likely to engage in parenting responsibilities (Coltrane et al. 2004). Some studies have emphasized the relationship between traditional and egalitarian (non-traditional) attitudes and 
parenting practices (Marks et al. 2009; Sabattini \& Leaper 2004). Marks et al. (2009) suggested that traditional views and parenting styles might be related, implying the relationship between an authoritarian parenting style and the traditional approach to gender roles. It was also reported that traditional paternal attitudes toward household labor and specifically childcare were associated with disengaged parenting, whereas egalitarian attitudes were linked to an authoritative parenting style (Sabattini \& Leaper 2004). Moreover, while maternal traditional attitudes were related to the authoritarian style, egalitarian attitudes were associated with a permissive style of parenting (Sabattini \& Leaper 2004).

When looking more specifically at families in Turkey, traditional attitudes seem to be maintaining their impact on parenthood (Erkal et al. 2007). Although some recent studies have focused on paternal involvement in childcare (Uludağlı 2017; Ünlü-Çetin \& Olgan 2021) and interventions have been conducted to increase paternal involvement (K1lıç 2010), mothers are still perceived as the primary caregivers and are more involved in childcare compared to fathers. Mothers tend to engage in more interaction with, take more responsibility for, and be more accessible to their children (Erkal et al. 2007). Therefore, there is a need for a culturally appropriate, valid, and reliable scale to measure these attitudes.

Although various scales exist for measuring traditional and non-traditional gender role attitudes (García-Cueto et al. 2015; Kerr \& Holden 1996), these measurements are insufficient in the context of traditionality and modernity in parenting. The Traditional Motherhood Scale (TMS) and Traditional Fatherhood Scale (TMS) (Whatley \& Knox 2005) were designed to measure traditional views about motherhood and fatherhood separately. Both scales were adapted into Turkish by Altınbilek (2012) and Yurtsever Kılıçgün and Kılıçkaya (2016, 2018). In Altınbilek's study (2012), the attitudes of university students toward traditional motherhood and fatherhood were investigated. Moreover, in Yurtsever Kılıçgün and Kılıçkaya's studies (2016, 2018), the scales' reliability and validity were confirmed for Turkish parents with children aged between 3 and 6 years. Both scales investigated individuals' attitudes concerning parenthood according to their own and society's beliefs and perceptions. Although the Turkish versions of the scales were found to have good psychometric properties, there are still some concerns regarding the possibility of adequate measurement. The most crucial point to be considered is that all items in the TMS have a positive connotation and motherhood is aggrandized, as exemplified by items such as "Motherhood is what brings women to their fullest potential" and "The mother has a better relationship with her children." As opposed to the TMS, the TFS consists of statements with negative connotations, such as "Fathers should never stay 


\section{Development of the Inventory of Traditional and Modern Approaches to Parenting: Reliability and Validity}

at home with the children while the mother works" and "Fathers punish children more than mothers do." The presence of positive items on one scale and negative items on the other may result in subjects responding in socially desirable ways; accordingly, ceiling or floor effects may occur. For that reason, there is a clear need to focus on both positive and negative statements in any scale. A new measurement tool was therefore developed in this work to balance such statements by adding egalitarian parenthood-related items. In addition, some TMS and TFS items may not have facilitated proper translation into Turkish. For instance, the item "Most men make horrible fathers [Birçok erkek kötü babadır]" may create a negative impression for the respondent or "Mothers are more sympathetic to children who have hurt themselves [Anneler kendilerini inciten çocuklara daha anlayışlı davranır]" may not be understood correctly. In light of such problematic items, the new scale presented here was developed to measure traditional attitudes toward parenthood and address the problems and shortcomings of previous scales. Furthermore, in earlier studies conducted in the Turkish context (Altınbilek 2012; Yurtsever Kılıçgün \& Kılıçkaya 2016, 2018), the attitudes of either university students or parents with children in a particular age range were examined and the TMS and TFS were validated for those participants. However, we suggest that parents' attitudes toward parenting may change based on the differing ages of their children. Accordingly, the new scale was designed to extend the age range of the children of participating parents. In contrast, the usage of the previous scales has occurred in parallel with a lack of measurement of traditional and modern approaches to parenting for parents having children in a wider age range.

The Parental Modernity Scale is also used to assess parents' attitudes toward childrearing and educational beliefs (Schaefer \& Edgerton 1985). This scale has two factors, namely parental traditionality and parental modernity. Parental traditionality is evaluated with items referring to authoritarian practices, whereas parental modernity is evaluated with items emphasizing progressive and democratic practices. While this scale does focus on parental traditionality and modernity attitudes in terms of practices, it does not address traditional and non-traditional gender roles. Furthermore, although this scale has been used in recent years (Tocu 2014), it was developed three decades earlier and attitudes may have changed since 1985.

For these reasons, it was aimed to develop a reliable and valid attitude scale to examine traditionality and modernity in parenting and investigate their psychometric properties. Based 
on the literature, the present study was begun with the assumption that traditional parenthood attitudes would depend on traditional gender role attitudes and the adoption of an authoritarian parenting style. At the same time, it was assumed that modern parenthood attitudes would be based on egalitarian views in childcare and an authoritative parenting style.

\section{Method}

\section{Participants}

A total of 513 mothers (Sample I), 106 fathers (Sample II), and 356 mothers (Sample III; Bayram Gülaçt, H. G. 2020) who had at least one child between the ages of 0 and 18 years participated in this study. Due to the unequal number of participating mothers $(n=513)$ and fathers $(n=106)$, both principal component analysis (PCA) and primary confirmatory factor analysis (CFA) were conducted based on the data gathered from the mothers $(N=513)$ (Sample I). Another CFA was then conducted for fathers to confirm the data fit for fathers (Sample II), as well. A third CFA was undertaken for mothers in a separate sample including 356 mothers who had at least one child attending school from the 5th grade to the 12th grade (Sample III). Sample III of this study consists of mothers who had participated within the scope of the author's $\mathrm{PhD}$ thesis and those analyses were performed as part of the $\mathrm{PhD}$ research (Bayram Gülaçtı, H. G. 2020). Descriptive statistics for the samples are given in Table 1.

Table 1. Descriptive Statistics for Samples I, II, and III

\begin{tabular}{lccccc}
\hline $\begin{array}{l}\text { Sample I (mothers in the main data pool for } \\
\text { PCA and CFA) }\end{array}$ & $N$ & $M$ & $S D$ & Min & Max \\
\hline Age & 502 & 33.06 & 7.17 & 20.00 & 52.00 \\
Education & 512 & 4.23 & 1.24 & 1.00 & 6.00 \\
\hline $\begin{array}{l}\text { Sample II (fathers in the main data pool for } \\
\text { CFA) }\end{array}$ & $N$ & $M$ & $S D$ & Min & Max \\
\hline Age & 98 & 41.08 & 8.22 & 20 & 72 \\
Education & 106 & 4.47 & 1.07 & 1.00 & 6.00 \\
\hline $\begin{array}{l}\text { Sample III (mothers in the separate data pool } \\
\text { for CFA) }\end{array}$ & $N$ & $M$ & $S D$ & Min & Max \\
\hline Age & 354 & 40.45 & 4.27 & 29.00 & 55.00 \\
Education & 353 & 2.46 & 1.43 & 1.00 & 6.00 \\
\hline
\end{tabular}

Considering the education levels of the participating mothers (Sample I), 8.4\% had graduated from primary or middle school, $23.2 \%$ had a high school diploma, $57.3 \%$ had a two- 


\section{Development of the Inventory of Traditional and Modern Approaches to Parenting: \\ Reliability and Validity}

year college or university degree, and $10.9 \%$ had either a master's or $\mathrm{PhD}$ degree. More than half of the mothers $(58.7 \%)$ reported perceiving their socioeconomic status (SES) as a middle SES.

Considering the education levels of the fathers (Sample II), $4.7 \%$ had graduated from primary or middle school, $15.1 \%$ had a high school diploma, $70.7 \%$ had a two-year college or university degree, and 9.4\% had a master's or $\mathrm{PhD}$ degree. The majority of the fathers perceived themselves as middle SES families.

In Sample III, $36.8 \%$ of the mothers had a primary school diploma, $16.6 \%$ had a middle school diploma, 28.4\% had graduated from high school, 3.4\% had graduated from a two-year college, $13.5 \%$ had a university degree, and $1.4 \%$ had a master's or $\mathrm{PhD}$ degree.

\section{Measures}

Demographic Information Sheet. This form included demographic statements or questions addressing the age, gender, education level, education of the spouse, number of children, income level, and perceived SES of the participants.

Ambivalent Sexism Inventory (ASI). The ASI is a 22-item self-report scale to assess attitudes toward sexism. It was originally developed by Glick and Fiske (1996) and was adapted to Turkish by Sakall1-Uğurlu (2002). It includes two factors: a) hostile sexism (11 items) and b) benevolent sexism (11 items). Hostile sexism is measured by items such as "Women seek power by gaining control over men" and "Women are too easily offended" while benevolent sexism is measured by items such as "Women have a superior moral sensibility" and "Men are incomplete without women." The scale was designed as a 6-point Likert-type scale where $1=$ Totally disagree, $2=$ Disagree, $3=$ Somewhat disagree, $4=$ Somewhat agree, $5=$ Agree, and 6 $=$ Totally agree. The Cronbach alpha scores of the subscales in the Turkish version were found to be .86 for hostile sexism and .78 for benevolent sexism. In the current study, the data collected from mothers indicated that the Cronbach alpha scores were .85 for hostile sexism and .82 for benevolent sexism.

The Traditional Motherhood Scale (TMS) (Whatley \& Knox, 2005). The TMS is an 18-item scale used to assess attitudes about traditionalism in motherhood and it has been adapted to Turkish (Altınbilek 2012). This 7-point Likert-type scale measures the traditional views of motherhood with two factors. The first factor measures thoughts about individual perceptions related to motherhood with 8 items. The second factor assesses thoughts about acts, 
society, and traditions concerning motherhood with 10 items. The reliability coefficient of the total scale was .93 in the Turkish adaptation. The total score was used in the current study, with higher scores representing more traditional views about motherhood. The Cronbach alpha of the total score was .92 for mothers in the current study.

The Traditional Fatherhood Scale (TFS) (Whatley \& Knox, 2005). The TFS includes 10 items measuring views about traditional fatherhood and it was adapted to Turkish (Altınbilek 2012). Like the TMS, it is a 7-point Likert-type scale with two factors. The reliability coefficient of the total scale was .80 in the Turkish version. Similar to the TMS, the total score was used in the current study with higher scores representing more traditional views about fatherhood. The Cronbach alpha of the total score was .79 in the current study.

Inventory of Traditional and Modern Approaches to Parenting (ITMAP). The ITMAP was developed by the authors of the current study to measure attitudes toward traditional and modern approaches to parenting and parental role division in the family.

Development of the ITMAP. As the first step in the development of the ITMAP, the literature was reviewed to identify possible factors reflecting traditionality and modernity in parenthood. Based on the literature, several items were selected by nine graduate students from developmental and social psychology programs and a faculty member of the Department of Psychology. As the second step, interviews were carried out with six parents to generate additional items. After writing 72 items, the scale was given to a group of psychology graduate students for evaluation of the items in terms of content, grammar, and face validity. Based on this evaluation and a final review of the scale by the authors, 10 items were deleted. After making the necessary changes to the scale, a 62-item final version was formed, data were collected, and analyses were performed based on these items.

Final Version of the ITMAP. This 15-item scale is composed of two factors: the traditional approach and the modern approach to parenting. The traditional approach is measured with 9 items (e.g. "Fathers should take a more active role in disciplining the child/Çocuğu disiplin etmede babalar daha etkin bir rol almalıdır" and "When children have a problem, they should first share it with their mothers/Çocuklar bir sıkıntıları olduğunda öncelikle bunu anneleriyle paylaşmalıdır." The modern approach is measured with 6 items (e.g. “Children's opinions should also be taken when making decisions at home/Evde kararlar alınırken çocukların da fikirleri alınmalıdır" and "Parents should support their children in expressing themselves/Ebeveynler çocuklarını kendilerini ifade etmeleri konusunda 


\section{Development of the Inventory of Traditional and Modern Approaches to Parenting: Reliability and Validity}

desteklemelidir."). The ITMAP was designed as a 6-point Likert-type scale with possible responses ranging from 1 ("Totally disagree") to 6 ("Totally agree").

\section{Procedure}

Ethical approval was first obtained from the Human Subjects Ethics Committee of Middle East Technical University. The scales were then distributed to participants in a paperand-pencil format or an online format using Qualtrics. In paper-and-pencil format, data were gathered from the three different cities of Ankara, Denizli, and Erzincan, whereas in an online format data were collected from a number of cities. Before the scales were administered, participants signed the informed consent form, and all participants voluntarily participated in the study. Confidentiality was also guaranteed. Participants completed the demographic information sheet, ITMAP, ASI, TMS, and TFS.

\section{Results}

\section{Construct Validity}

In order to form a reliable and valid scale investigating traditional and modern approaches to parenting, exploratory factor analyses including PCA and CFA were conducted using mother-only data (Sample I) due to the unequal numbers of participating mothers and fathers. CFA was then conducted using father-only data (Sample II) to confirm the scale for fathers and again using separate mother-only data (Sample III) to confirm the scale with another data pool obtained from mothers.

Principal Component Analysis (PCA). Before conducting factor analyses, correlations between the items were checked and found to be at low to moderate levels; thus, we decided to include all items in the analysis (with Sample I). In order to check the factorability of the data, Tabachnick and Fidell (2013)'s recommendations were followed. First, the Kaiser-MeyerOlkin measure of sampling adequacy was investigated. The result was found to be .86, which is above the cut-off point of .5 , and Bartlett's test of sphericity was significant $\left(\chi^{2}(1891)=\right.$ 8853.566, $p<.001$ ). Based on these statistical results, the data could be analyzed with PCA. The scree plot and eigenvalues were then examined. The initial result demonstrated that there were 18 components with eigenvalues of greater than 1 explaining $58.59 \%$ of the total variance. However, the scree plot revealed that a two-factor solution was appropriate.

PCA with oblique rotation was repeated by restricting the number of factors to two. In the analysis, a two-factor solution explained $22.77 \%$ of the total variance. The items were 
retained on each factor if they had loadings above .40 (Howard 2016). Communalities were also checked in order to explore the common variance for the items. For the communalities of the items, those items with low communality scores were excluded as recommended by Costello and Osborne (2005). There is uncertainty regarding the cut-off score for communalities and it has been suggested that it is arbitrary (Santos et al. 2019). Exclusion of the items showing communality scores lower than .20 (Child 2006), .30 (Ibikunle et al. 2015), and .40 (Suni \& Pesonen 2019) has been advocated by different researchers. In the current study, 47 items with communality scores of $\leq .30$ were excluded from further analyses. Finally, a two-factor solution explained $45.28 \%$ of the total variance $(31.31 \%$ and $13.97 \%$ for the first and second factors, respectively) and it was accepted as the final structure. The first factor was named traditional approach (9 items) and the second factor was named modern approach (6 items) (see Table 2 for the factor structure of the ITMAP). Based on the PCA results, the factor loadings of the first factor were between .57 and .74 while the factor loadings of the second factor ranged between .56 and .76 (see Table 2).

Table 2. Factor Loadings of Traditional and Modern Approaches to Parenting Based on PCA and CFA

\begin{tabular}{|c|c|c|c|c|}
\hline \multirow[b]{2}{*}{ Factors/Items } & \multicolumn{2}{|c|}{$\begin{array}{l}\text { Mother-Only Data } \\
\quad \text { (Sample I) }\end{array}$} & $\begin{array}{c}\text { Father- } \\
\text { Only } \\
\text { Data } \\
\text { (Sample } \\
\text { II) }\end{array}$ & $\begin{array}{l}\text { Mother } \\
\text { Data } \\
\text { (Sample } \\
\text { III) }\end{array}$ \\
\hline & 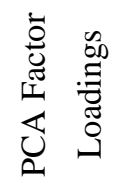 & 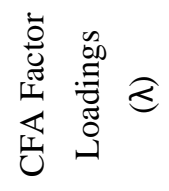 & 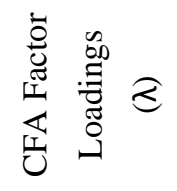 & 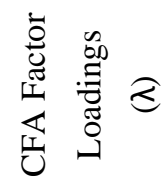 \\
\hline \multicolumn{5}{|l|}{ Factor 1: Traditional Approach } \\
\hline $\begin{array}{l}\text { I think that fathers have a more decisive } \\
\text { role than mothers in planning the future of } \\
\text { their children. }\end{array}$ & .742 & $.634^{* * * *}$ & $.483^{* * *}$ & $.678^{* * *}$ \\
\hline $\begin{array}{l}\text { I think that while mothers are responsible } \\
\text { for the child's daily needs, fathers are } \\
\text { responsible for their future needs. }\end{array}$ & .738 & $.703^{* * *}$ & $.696^{* * *}$ & $.680^{* * * *}$ \\
\hline $\begin{array}{l}\text { When children misbehave, it is better for } \\
\text { their father to warn them. }\end{array}$ & .726 & $.670^{* * * *}$ & $.761^{* * * *}$ & $.679^{* * * *}$ \\
\hline $\begin{array}{l}\text { When children want permission for } \\
\text { something, they should first ask their } \\
\text { fathers. }\end{array}$ & .673 & $.647^{* * *}$ & $.788^{* * *}$ & $.568^{* * *}$ \\
\hline
\end{tabular}




\section{Development of the Inventory of Traditional and Modern Approaches to Parenting: \\ Reliability and Validity}

Table 2 (Continued).

\begin{tabular}{|c|c|c|c|c|c|}
\hline \multirow[b]{2}{*}{ Factors/Items } & \multicolumn{3}{|c|}{$\begin{array}{l}\text { Mother-Only Data } \\
\quad \text { (Sample I) }\end{array}$} & \multirow{2}{*}{ 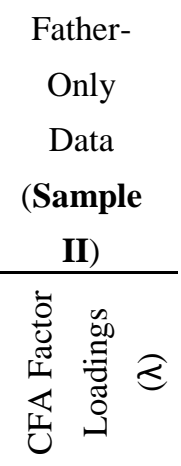 } & \multirow{2}{*}{ 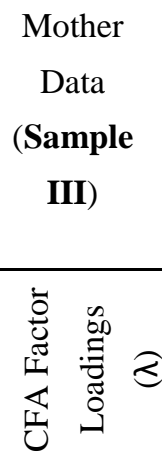 } \\
\hline & 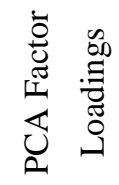 & & 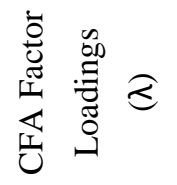 & & \\
\hline $\begin{array}{l}\text { Fathers should take a more active role in } \\
\text { disciplining the child. }\end{array}$ & .647 & & $.530^{* * * *}$ & $.461^{* * * *}$ & $.494^{* * * *}$ \\
\hline $\begin{array}{l}\text { Father's words should be the most valid } \\
\text { ones at home. }\end{array}$ & .632 & & $.570^{* * *}$ & $.594^{* * *}$ & $.575^{* * * *}$ \\
\hline $\begin{array}{l}\text { When children have a problem, they } \\
\text { should first share it with their mothers. }\end{array}$ & .627 & & $.575^{* * *}$ & $.627^{* * *}$ & $.575^{* * * *}$ \\
\hline $\begin{array}{l}\text { Fathers are responsible for meeting the } \\
\text { financial needs of their children. }\end{array}$ & 600 & & $.595^{* * *}$ & $.791^{* * *}$ & $.603^{* * *}$ \\
\hline $\begin{array}{l}\text { Meeting the child's basic needs (such as } \\
\text { eating, sleeping, toilet) should mostly be } \\
\text { the mother's responsibility. } \\
\text { Factor 2: Modern Approach }\end{array}$ & .566 & & $.617^{* * *}$ & $.617^{* * *}$ & $.634^{* * *}$ \\
\hline $\begin{array}{l}\text { Parents should share the workload in } \\
\text { raising children. }\end{array}$ & & .757 & $.656^{* * *}$ & $.565^{* * *}$ & $.688^{* * * *}$ \\
\hline $\begin{array}{l}\text { Fathers should be as knowledgeable as } \\
\text { mothers about raising children. }\end{array}$ & & .708 & $.667^{* * *}$ & $.547^{* * *}$ & $.694^{* * * *}$ \\
\hline $\begin{array}{l}\text { I think that parents should perceive their } \\
\text { children as individuals and regulate their } \\
\text { behavior accordingly. }\end{array}$ & & .701 & $.605^{* * *}$ & $.756^{* * *}$ & $.699^{* * * *}$ \\
\hline $\begin{array}{l}\text { When necessary, the father should also be } \\
\text { able to comb the hair of his daughters. }\end{array}$ & & .652 & $.586^{* * *}$ & $.559^{* * * *}$ & $.680^{* * * *}$ \\
\hline $\begin{array}{l}\text { Parents should support their children in } \\
\text { expressing themselves. }\end{array}$ & & .583 & $.503^{* * *}$ & $.668^{* * * *}$ & $.688^{* * * *}$ \\
\hline $\begin{array}{l}\text { Children's opinions should also be taken } \\
\text { when making decisions at home. }\end{array}$ & & .563 & $.447^{* * *}$ & $.565^{* * *}$ & $.622^{* * * *}$ \\
\hline
\end{tabular}

Note. Standardized parameters are shown; ${ }^{* * *} p<.001$

Confirmatory Factor Analysis (CFA). CFA was conducted with the AMOS 23 software program for the Inventory of Traditional and Modern Approaches to Parenting (ITMAP) to test the two-factor solution determined through PCA. Çokluk et al. (2010) suggested that a model is acceptable when the following fit criteria are met: $\chi^{2} / d f<5, \mathrm{TLI} \geq .90, \mathrm{CFI} \geq .90$, and RMSEA 
$\leq .08$. Based on these criteria, CFA conducted with mother-only data (Sample I) showed an acceptable model fit: $\chi^{2} / d f=2.99, p<.001, \mathrm{CFI}=.91, \mathrm{TLI}=.90, \mathrm{RMSEA}=.06$.

In addition, CFA was conducted for data obtained from fathers (Sample II) to determine whether or not this scale structure could be applied to fathers. Similar to the former analysis run with mother-only data, the model indicated an acceptable model fit with the data from fathers: $\chi^{2} / d f=1.419, p=.006, \mathrm{CFI}=.93, \mathrm{TLI}=.92, \mathrm{RMSEA}=.06$.

Lastly, CFA was applied to show the construct validity of the scale with data from another sample of mothers (Sample III). These results again indicated an acceptable model fit: $\chi^{2} / d f=2.54, p<.001, \mathrm{CFI}=.92, \mathrm{TLI}=.90, \mathrm{RMSEA}=.07$.

\section{Criterion-Related Validity}

After the determination of a two-factor solution, the criterion-related validity of the ITMAP was tested through the correlations between the factors and other related constructs. For this purpose, Pearson correlation coefficients were calculated for mother-only data (Sample I). Descriptive statistics for the scale are given in Table 3 and the results of bivariate correlations are given in Table 4. The moderate and significant correlations between the factors (traditional and modern approaches to parenting), the TMS, the TFS, and the ASI demonstrated that the ITMAP has good criterion-related validity. Specifically, the traditional approach to parenting was negatively associated with the modern approach to parenting $(r=-.346, p<.001)$ but positively associated with the TMS $(r=.538, p<.001)$, the TFS $(r=-.455, p<.001)$, benevolent sexism $(r=.586, p<.001)$, and hostile sexism $(r=.381, p<.001)$. In contrast, the modern approach to parenting was negatively associated with the TFS $(r=-.203, p<.001)$ while the negative correlation between the modern approach to parenting and hostile sexism indicated marginal significance $(r=-.008, p=.06)$.

Table 3. Descriptive Statistics of the ITMAP, ASI, TMS, and TFS Scores for Mother-Only Data (Sample I)

\begin{tabular}{lcc}
\hline & $M$ & $S D$ \\
\hline Traditional approach & 2.752 & .959 \\
Modern approach & 5.575 & .423 \\
TMS (Traditional Motherhood Scale) & 5.446 & .985 \\
TFS (Traditional Fatherhood Scale) & 2.864 & 1.031 \\
Hostile sexism (Ambivalent Sexism Inventory, ASI) & 3.477 & .953 \\
Benevolent sexism (Ambivalent Sexism Inventory, ASI) & 3.712 & .902 \\
\hline
\end{tabular}




\section{Development of the Inventory of Traditional and Modern Approaches to Parenting: Reliability and Validity}

Table 4. Correlations between Traditional and Modern Approaches to Parenting, TMS (Traditional Motherhood), TFS (Traditional Fatherhood), and ASI (Hostile and Benevolent Sexism) for Mother-Only Data (Sample I)

\begin{tabular}{|c|c|c|c|c|c|c|}
\hline & $\begin{array}{c}\text { Traditional } \\
\text { approach }\end{array}$ & $\begin{array}{l}\text { Modern } \\
\text { approach }\end{array}$ & TMS & TFS & $\begin{array}{l}\text { Hostile } \\
\text { sexism }\end{array}$ & $\begin{array}{l}\text { Benevolent } \\
\text { Sexism }\end{array}$ \\
\hline $\begin{array}{l}\text { Traditional } \\
\text { approach }\end{array}$ & 1 & $-.346^{* * *}$ & $.538^{* * * *}$ & $.455^{* * *}$ & $.381^{* * * *}$ & $.586^{* * *}$ \\
\hline $\begin{array}{l}\text { Modern } \\
\text { approach }\end{array}$ & & 1 & -087 & $-.203^{* * * *}$ & $-.008^{\mathrm{a}}$ & -.044 \\
\hline
\end{tabular}

\section{Reliability}

In order to check whether the scale was reliable or not, internal consistencies were estimated for the two factors separately. The internal reliabilities showed that the Cronbach alpha coefficients for mothers (Sample I) were .85 for "traditional approach" and .75 for "modern approach." The Cronbach alpha coefficients for fathers (Sample II) were .87 for "traditional approach" and .78 for "modern approach," while for the mothers in Sample III, they were .84 for "traditional approach" and .84 for "modern approach." These scores indicate quite high internal reliability for the ITMAP.

\section{Discussion}

There are some measurement tools assessing parental traditionality and/or modernity (Whatley \& Knox 2005; Schaefer \& Edgerton 1985); however, none of them include both traditional and egalitarian views for both fathers and mothers. It is important to assess these attitudes with culturally appropriate, reliable, and valid measurements. Therefore, in the current study, it was aimed to develop a reliable and valid scale assessing parents' traditional and modern attitudes to parenting. The findings of the current study indicate that the ITMAP is a reliable and valid scale including two factors, namely traditional approaches and modern approaches.

Although the TMS and TFS (Whatley \& Knox 2005) are instruments designed for measuring attitudes toward traditional parenthood, as mentioned above, these scales are not able to evaluate modern approaches toward parenthood and they focus on stereotypes, being applicable only for mothers and only for fathers as two separate scales. Moreover, the TMS emphasizes positive thoughts about motherhood but the TFS emphasizes negative aspects of fatherhood with items lacking in semantic nuance. Finally, these scales were validated in 
Turkish for university students (Altınbilek 2012) and parents with children between the ages of 3 and 6 years (Yurtsever Kılıçgün \& Kılıçkaya 2016, 2018). Some concerns have also arisen about the Parental Modernity Scale (Schaefer \& Edgerton 1985). It could be described as outdated and it focuses on traditional and progressive parenting practices rather than parental gender roles or role division in childcare. However, the ITMAP evaluates both modern and traditional thoughts on parenting from a more general point of view. In particular, the ITMAP emphasizes traditional and progressive parenting styles as well as parental traditional and egalitarian roles in childcare for parents with children of a wider age range. In that respect, it can be suggested that the ITMAP has closed this measurement gap in the literature.

The new scale also offers good psychometric properties in terms of reliability and validity as verified by factor, correlation, and reliability analyses. The coherent factor structure indicates two different but associated constructs of parenthood in terms of traditionalism and modernity. Furthermore, significant correlations between the factors of traditional and modern approaches in the ITMAP and the TMS, the TFS, and the ASI (benevolent and hostile sexism) were also found. Results showed that mothers with high levels of hostile and benevolent sexism toward women reported more traditional approaches to parenting. Those individuals focused on stereotypical gender roles in parenting, in line with previous findings in the literature. For instance, benevolent sexism and hostile sexism were found to be linked with men's authority and women's low status, referred to as traditional gender roles in marriages (Chen et al. 2009). Furthermore, mothers with lower scores of hostile sexism toward women had a tendency to engage in modern approaches to parenting. It could be speculated that parents with less hostile sexist attitudes toward women tend to see women and men in a more egalitarian way, being less likely to behave according to traditional gender roles. There were also significant correlations between traditional/modern approaches and traditional motherhood and fatherhood. Mothers with higher TMS and TFS scores were more likely to report more traditional views about parenting. In contrast, more egalitarian and modern individuals reported fewer stereotypical thoughts about motherhood and fatherhood roles. In this regard, not only the findings from factor analyses but also the moderate yet significant correlations between the constructs showed that the ITMAP is a valid measurement tool. CFA performed with different datasets (Samples II and III) further supported the factor structure of the scale determined with Sample I. In addition to its confirmed validity, the ITMAP was found to be a reliable measure for investigating traditional and modern approaches to parenting as the internal reliabilities showed coefficients ranging between .75 and .87 (Cortina 1993). 


\section{Development of the Inventory of Traditional and Modern Approaches to Parenting: \\ Reliability and Validity}

\section{Limitations and Future Suggestions}

The current study has contributed to the literature with the development of an index assessing traditional and modern approaches to parenting with good psychometric properties. However, there are some limitations, as well. First, data were obtained with two different approaches: paper-and-pencil and online distribution of scales. However, paper-and-pencil and online formats were found to yield similar results in the literature (Anderson et al. 2005). Second, the responses given to items evaluating the modern approach may have been influenced by social desirability bias as parents might have reported their expectations or idealized approaches to parenting. Therefore, it should be kept in mind that these responses may reflect beliefs and attitudes rather than actual behaviors. Last but not least, analyses were conducted with separate samples. First, mother and father samples were divided as Samples I and II because of the unbalanced sample sizes. Moreover, Sample III of this study comprised mothers who had participated within the scope of the author's $\mathrm{PhD}$ thesis and those analyses were based on data collected from only mothers. Thus, the reliability and validity of the scale were evaluated with a second sample including mothers. In future studies, the scale could be further validated with whole parent samples including both mothers and fathers.

\section{Conclusion}

The present study has provided a reliable and valid scale for researchers to investigate parents' traditional and modern attitudes toward parenting. The development of this scale in the Turkish cultural context has contributed to the national literature, and further research examining the relationship between these constructs and other mechanisms may provide more guidance for family studies in Turkey.

\section{Acknowledgement}

I would like to thank Prof. Dr. Sibel Kazak Berument for her supervision and supportive feedback during the manuscript writing process.

\section{REFERENCES}

Altınbilek, E. S. (2012). Turkish translation and validity-reliability study of traditional motherhood and fatherhood scales, Unpublished Master Thesis, Near East University.

Anderson, H. M., Cain, J. \& Bird, E. (2005). Online student course evaluations: Review of literature and a pilot study, American Journal of Pharmaceutical Education, 69(1), 34 43.

Bartlett, M. S. (1954). A further note on the multiplying factors for various chi-square approximations in factor analysis, Journal of the Royal Statistical Society, 16, 296-298. 
Bartley, S. J., Blanton, P. W. \& Gilliard, J. L. (2005). Husbands and wives in dual-earner marriages: Decision-making, gender role attitudes, division of household labor, and equity, Marriage \& Family Review, 37(4), 69-94.

Bayram Gülaçt, H. G. (2020). The Predictors of Parental Differential Treatment and Dyadic Relations with Sibling Attachment, Unpublished doctoral dissertation, Ankara- Middle East Technical University.

Bernhardt, E., Goldscheider, F. (2006). Gender equality, parenthood attitudes, and first births in Sweden, Vienna Yearbook of Population Research, 4, 19-39.

Blackstone, A. (2003). Gender roles and society, In J. R. Miller, R. M. Lerner \& L. B. Schiamberg (Eds.), Human Ecology: An Encyclopedia of Children, Families, Communities, and Environments (335-338), Springer.

Chen, Z., Fiske, S. T. \& Lee, T. L. (2009). Ambivalent sexism and power-related gender-role ideology in marriage, Sex Roles, 60(11-12), 765-778.

Child, D. (2006). The essentials of factor analysis, London: Continuum International Publishing Group.

Coltrane, S., Parke, R. D. \& Adams, M. (2004). Complexity of father involvement in lowincome Mexican American families, Family Relations, 53(2), 179-189.

Copur, Z., Erkal, S., Dogan, N. et al. (2010). Sharing and spending time on domestic tasks: A Turkish sample. Journal of Comparative Family Studies, 41(1), 87-109.

Copur, Z., Erkal, S., Dogan, N. et al. (2007). Relationship between Gender Roles in the Family and Performing Domestic Tasks, Indian Journal of Social Work, 68(2), 259-281.

Corrigall, E. A., Konrad, A. M. (2007). Gender role attitudes and careers: A longitudinal study, Sex Roles, 56(11), 847-855.

Cortina, J. M. (1993). What is coefficient alpha? An examination of theory and applications, Journal of Applied Psychology, 78(1), 98-104.

Costello, A. B., Osborne, J. W. (2005) Best practices in exploratory factor analysis: four recommendations for getting the most from your analysis, Practical Assessment, Research \& Evaluation, 10(7), 1-9.

Erkal, S., Copur, Z., Dogan, N. et al. (2007). Examining the Relationship Between Parents' Gender Roles and Responsibilities towards Their Children (A Turkish Example), Social Behavior and Personality: An International Journal, 35(9), 1221-1234.

García-Cueto, E., Rodríguez-Díaz, F. J., Bringas-Molleda, C. et al. (2015). Development of the gender role attitudes scale (GRAS) amongst young Spanish people, International Journal of Clinical and Health Psychology, 15(1), 61-68.

Glick, P., Fiske, S. T. (1996). The ambivalent sexism inventory: Differentiating hostile and benevolent sexism, Journal of Personality and Social Psychology, 70(3), 491-512.

Howard, M. C. (2016). A review of exploratory factor analysis decisions and overview of current practices: What we are doing and how can we improve?, International Journal of Human-Computer Interaction, 32(1), 51-62.

Ibikunle, P. O., Oladipo, S. E., Chukwu, J. N. et al. (2015). Establishing the reliability and construct validity of the Igbo version of screening activity limitation and safety awareness scale in persons with Hansen disease, Leprosy Review, 86(3), 220-228. 


\section{Development of the Inventory of Traditional and Modern Approaches to Parenting: \\ Reliability and Validity}

Kerr, P. S., Holden, R. R. (1996). Development of the gender role beliefs scale (GRBS), Journal of Social Behavior and Personality, 11(5), 3-16.

Kılıç, Ç. (2010). Aile eğitim programları ve Türkiye'deki örnekleri, Abant İzzet Baysal Üniversitesi Eğitim Fakültesi Dergisi, 10(1), 99-111.

Marks, J. L., Lam, C. B. \& McHale, S. M. (2009). Family patterns of gender role attitudes, Sex Roles, 61(3-4), 221-234.

Nangle, S. M., Kelley, M. L., Fals-Stewart, W. et al. (2003). Work and family variables as related to paternal engagement, responsibility, and accessibility in dual-earner couples with young children, Fathering, 1(1), 71-90.

Rogers, S. J., Amato, P. R. (2000). Have changes in gender relations affected marital quality?, Social Forces, 79(2), 731-753.

Sabattini, L., Leaper, C. (2004). The relation between mothers' and fathers' parenting styles and their division of labor in the home: Young adults' retrospective reports, Sex Roles, 50(34), 217-225.

Sakallı-Uğurlu, N. (2002). Çelişik duygulu cinsiyetçilik ölçeği: Geçerlik ve güvenirlik çalışması, Türk Psikoloji Dergisi, 17(49), 47-58.

Santos, R. D. O., Gorgulho, B. M., Castro, M. A. D. et al. (2019). Principal component analysis and factor analysis: Differences and similarities in nutritional epidemiology application, Revista Brasileira de Epidemiologia, 22(2), e190041.

Schaefer, E. S., Edgerton, M. (1985). Parent and child correlates of parental modernity, I. E. Sigel (Ed.), Parental belief systems: The psychological consequences for children (287318), Hillsdale, NJ: Erlbaum.

Scott, J. (2006). Family and gender roles: How attitudes are changing, GeNet Working Paper No. 21.

Suni, J., Pesonen, J. (2019). Hunters as tourists-an exploratory study of push-pull motivations, Scandinavian Journal of Hospitality and Tourism, 19(2), 175-191.

Tabachnick, B., Fidell, L. (2013). Using Multivariate Statistics, (6th ed.), Boston: Pearson.

Tocu, R. (2014). Study on the parental beliefs and attitudes towards child rearing and education, Procedia-Social and Behavioral Sciences, 137, 153-157.

Uludağlı, N. P. (2017). Baba katılımında etkili faktörler ve baba katılımının baba, anne ve çocuk açısından yararları, Türk Psikoloji Yazıları, 20(39), 70-92.

Ünlü-Çetin, Ş., Olgan, R. (2021). The effect of perceived intergenerational paternal involvement on fathers' involvement in the lives of their 0-to-8-year-old children, Early Child Development and Care, 191(1), 93-107.

Whatley, M., Knox, D. (2005). Scales for measuring college student views of traditional motherhood and fatherhood, College Student Journal, 39(3), 588-596.

Yurtsever Kılıçgün, M., Kılıçkaya, A. (2016). Geleneksel Annelik Ölçeği'nin Psikometrik Özellikleri: Geçerlik ve Güvenirlik Çalışması, Itobiad: Journal of the Human \& Social Science Researches, 5(8), 2867-2881.

Yurtsever Kılıçgün, M., Kılıçkaya, A. (2018). Geleneksel Babalık Ölçeği'nin Psikometrik Özellikleri: Geçerlik ve Güvenirlik Çalışması. 1. Uluslararası Eğitimde Yeni Arayışlar Kongresi (146-148). İstanbul, Turkey. 
Çokluk, Ö., Şekercioğlu, G. \& Büyüköztürk, Ş. (2010). Sosyal Bilimler İ̧̧in Çok Değişkenli Istatistik: SPSS ve LISREL Uygulamalar, Ankara: Pegem Akademi. 
Development of the Inventory of Traditional and Modern Approaches to Parenting: Reliability and Validity 